\title{
Mulemba
}

Revista Angolana de Ciências Sociais

6 (12) | 2016

Sobre a sociedade e a cultura em Angola e alhures:

algumas reflexões de percepções sobre a realidade e múltiplas experiências

\section{Ver a «emoção». A kizomba de Angola para o mundo}

To see the "emotion». Angola's kizomba to the world

\section{Federica Toldo}

\section{(2) OpenEdition}

\section{Journals}

\section{Edição electrónica}

URL: http://journals.openedition.org/mulemba/951

DOI: 10.4000/mulemba.951

ISSN: 2520-0305

\section{Editora}

Edições Pedago

Edição impressa

Data de publição: 1 novembro 2016

Paginação: 145-178

ISSN: 2182-6471

Refêrencia eletrónica

Federica Toldo, «Ver a «emoção». A kizomba de Angola para o mundo», Mulemba [Online], 6 (12) | 2016, posto online no dia 30 setembro 2018, consultado o 26 janeiro 2021. URL: http://

journals.openedition.org/mulemba/951 ; DOl: https://doi.org/10.4000/mulemba.951 


\title{
Ver a «emoção». A kizomba de Angola para o mundo
}

\author{
Federica Toldo*
}

\begin{abstract}
Resumo: Com este trabalho pretendo estudar a difusão internacional de um tipo de dança de casal de origem angolana conhecida por kizomba e as suas consequentes transformações. As características específicas deste tipo de dança estão a ser codificadas e institucionalizadas na Europa através de ensino e competição internacional. Estes procedimentos (aulas e concursos de dança) assentam em algumas propriedades específicas desta dança, que procuro analisar neste artigo, e, ao propôr uma definição de kizomba como tipo de dança, pretendo igualmente demonstrar como a versão contemporânea internacional da mesma assenta sobretudo na ideia de sensualidade. Essa qualidade, que é atribuída à kizomba e que a circunscreve em movimentos e escolhas coreográficas específicas, constitui, sem dúvida, a ênfase fundamental da versão europeia.
\end{abstract}

Palavras-chave: Angola, kizomba, semba, rebita, zouk, danças, coreologia, coreografia, pesquisa etnográfica, antropologia visual, afectos, emoção, ensino, competição, transnacionalização, negritude, Mateus Pelé do Zangado.

\section{Introdução}

A difusão de práticas locais do corpo para fora do seu contexto de origem sempre apareceu associado a alguma transformação, pragmática e representacional, mais ou menos radical. Com a presente contribuição propomos como estudo de caso, a kizomba, dança de casal de origem angolana a qual é suposto o leitor conhecer. A sua penetração em outros contextos está sobretudo associado ao incremento de esforços tendentes à sua explicitação. Talvez pareça arriscado dizer

\footnotetext{
* Doutoranda em Antropologia Cultural e Etnologia pela Université de Paris Ouest, Nanterre-La Défense (França) e Instituto de Ciências Sociais (Ics) da Universidade de Lisboa (Portugal).
} 
que o incremento da reflexidade associada a uma prática do corpo afigura-se-nos em si mesmo um marcador da sua complexificação social, do surgimento de exigências e de instâncias que visam a sua patrimonialização, do incremento da concorrência pela legitimidade na sua difusão.

A kizomba enquanto género de dança de casal não foi objecto de estudo e de publicação em monografias. O termo kizomba é um nome genérico kimbundu, língua falada em Luanda e hinterland, cujo significado é «folguêdo; dança», «diversão; bailarico» (cf. Assis Jr., s.d.: 153). Izomba (plural de kizomba) é a designação de uma obra inigualável do conhecido etnógrafo angolano Óscar Ribas; ela tem por objecto o estudo das práticas recreativas e associativas baseadas nas danças da região de Luanda, que aí são também designadas por esse nome (Ribas 1965).

O estudioso aponta para algumas características das festas dançantes luandenses e da sua evolução ao longo do tempo. Ele fornece informações concernentes tanto a actuação coreográfica, quanto o contexto social. Danças, cuja característica coreográfica básica é constituída pela umbigada, isto é, o toque de umbigo que atravessa um processo de recontextualização espacial e que se traduz numa requalificação social. Uma vez que uma dança outrora praticada ao ar livre passa a ser praticada em sala, se afirmam regras mais selectivas de participação. Para participar nos bailes, é necessário preencher determinados requisitos que se baseiam na observação tanto de uma contribuição económica, quanto de códigos precisos, vestimentários e comportamentais, tal como, por exemplo, mútua assistência entre sócios.

Na época em que se situam as agremiações apresentadas, atraiu à massemba não apenas varões de baixo nível, mas também de nível médio. Não apenas gente negra, mas também mestiça e até europeus, na falta de clubes actuais, nela compareceram (RIBAS 1965: 26). Esta miscigenação característica do público masculino, se manifesta significativamente nos códigos de vestuário. Enquanto que as mulheres vestem preciosos panos à maneira autóctone luandense, aos homens é exigido o smoking (Idem: 28).

No entanto, dentre as danças aí repertoriadas e que são objecto dessa brilhante descrição efectuada por esse consagrado estudioso angolano, não encontramos nenhuma dança de casal.

Kizomba, enquanto dança de casal, apenas recentemente passou a ser objecto da atenção dos pesquisadores, atenção essa com certeza 
despertada pelo sucesso crescente e surpreendente que esta dança passou a gozar sobretudo na Europa.

No entanto, em geral, sabe-se muito pouco acerca dela. Daí a urgente necessidade de se documentar e a consequente procura de informação acerca dela constitui hoje matéria levantada nas redes sociais, onde os seus praticantes animam longas conversas e debates. Seduzidos por uma dança promovida no exterior por meio de termos da área semântica do sentir («sensual» in primis), estes dirigem-se à internet na esperança de aí encontrarem informações acerca dela.

A primeira especificidade dos discursos que procuram debater o que é kizomba é a sistemática derrapagem do discurso da dança para a música. ${ }^{1}$ Embora mobilize uma erudição histórico-musical, útil ou propriamente indispensável para quem queira saber mais, e, de repente, se consagrar ao ensino, este deslocamento de foco acaba por colocar à margem a prática da dança em si e para si.

A focalização do discurso sobre a música coloca em segundo plano as tentativas de explicitação da especificidade da dança e das suas possíveis variações. É em volta da música que se articula a diferenciação que orienta os aprendizes dançarinos europeus na escolha entre um ou outro tipo de noites dançantes. "Zouk retro, kizomba, semba», "Ghetto zouk, kizomba», por exemplo, seriam etiquetas que orientam os movimentos dos dançarinos, sendo a primeira uma fórmula mais destinada a interceptar os puristas e a segunda mais direccionada aos apreciadores das evoluções mais contemporâneas. Da mesma forma, é na música que se foca a maioria dos esforços de construção de uma sociologia cultural do meio do kizomba na Europa. No entanto, o modo de dançar não desperta suficiente atenção enquanto marcador de diferenças no seio desse meio, senão como consequência da música.

O principal objectivo desta contribuição é estimular a pesquisa sobre a maneira angolana de dançar em par, tanto na sua dimensão histórico-evolutiva e sociológica, quanto cultural. Mais especificamente, neste texto procura-se apontar etnograficamente para elementos que contribuam a identificar a especificidade de uma maneira angolana de dançar em par à luz da sua actual difusão.

\footnotetext{
1 Veja-se por exemplo a voz «O que é kizomba?» no site da plataforma internacional Kizomba Nation, que assegura a interconexão dos eventos de kizomba e a sua convergência na competição internacional «Africadançar»: <http:// www.kizombanation.com/pt/o-que-e-kizomba>.
} 
Para tal, a nossa abordagem consiste num esboço de análise coreológica, ${ }^{2}$ que se inscreve em uma proposta teórica mais abrangente de antepôr a uma análise musicológica da dança uma análise pragmática. Impõe-se-nos então a interrogação seguinte: Será kizomba um género de dança?

Propomos, como primeira aproximação, a utilização do termo kizomba para designar o modo angolano de dançar a dois, isto é, em par. Tratar-se-ia então de um género de dança cuja diferenciação em subgéneros, em função do tipo de música com que pode se acompanhar, é susceptível de ser associada à necessidade de particularizar o produto no quadro de um mercado recreativo e didáctico em rápido crescimento.

Conhecemos e praticamos a kizomba em três países europeus: desde 2010 em França e Portugal e, mais recentemente, na Itália, país em que chegou bastante mais tarde. Uma terreno de pesquisa etnográfica, que está sendo desenvolvido em Luanda desde 2013, permitiu-nos, enfim, conhecer a kizomba tal qual ela é ali praticada.

\section{Vontade de dançar, vontade de saber}

O fenómeno diante do qual estamos actualmente postos é a chegada da kizomba em novos territórios geográficos, onde o grande público que se inicia nessa dança, é já em grande maioria não lusófono e em princípio bastante pouco cientes das coisas de Angola. Paradigmático, neste sentido, é o caso da Itália onde a kizomba desembarcou bastante tardiamente, mas teve uma expansão tão rápida e acentuada, ao ponto de justificar, em 2014, a hospedagem do histórico festival Africadançar, que abriga o homónimo concurso internacional de kizomba (NeGro Francesca, inédito).

2 O termo Coreologia, que designa a disciplina académica dedicada às leis que regem o movimento humano, foi inaugurada por Rudolf Laban (cf. LABAN 1994). Entende-se, assim, que a aplicação do método coreológico de maneira específica à dança, tornou possível o surgimento de uma área específica de estudos, denominada Estudos Coreológicos. Ademais, a ideia de que a dança é inteligível sem passar pela música, inaugurada por Laban, passou a ser defendida pelos coreógrafos contemporâneos. A primeira versão da obra de Laban, The mastery of mouvement, foi editada em 1950. Ao longo do texto referir-nos-emos à versão francesa de 1994. 
O sucesso crescente da kizomba levou a um rápido acréscimo de demanda de aprendizagem. Assim, acontece que o maior número de agentes actualmente envolvidos no ensino desta dança no exterior não são angolanos.

Esta expansão territorial da kizomba foi suportada por uma crescente vontade de aprender. Como todo processo de difusão de práticas do corpo, a difusão da kizomba se associa igualmente ao incremento dos esforços de explicitação e de reflexividade.

A associação de vontade de aprender, vontade de dançar e vontade de saber constituíram uma poderosa embraiagem de difusão. No entanto, este conhecimento parcial, isto é, esta dúvida, deu vida a experimentações coreográficas cujos êxitos se distanciam bastante daquilo que um angolano reconheceria por kizomba. Mais em particular esta especulação coreográfica e esta busca pela dança foram largamente orientadas pela caracterização da kizomba enquanto dança «sensual».

O circuito didáctico e episódico da kizomba serve-se assim massivamente de nomes que evocam a emoção, a sensualidade, e, ainda, a tentação. A nível coreográfico, a ênfase posta em toda propriedade da dança que sublinhasse este caráter supostamente sensual foi por sua vez um dispositivo comercial essencial para alimentar esta vontade de dançar.

Enquanto permaneceu em Portugal, onde evidentes laços históricos e a presença de uma importante comunidade angolana possibilitaram desde sempre a prática social da dança, houve menores margens de interpretação do que é kizomba. Enquanto a kizomba se manteve num contexto lusófono, o debate reduzia-se à fricção entre angolanos e cabo-verdianos que se contendiam acerca da criação do género, focando o debate - uma vez mais - na sua dimensão musical. Com a sua saída paulatina da sua área de familiaridade cultural, no final da primeira década de 2000, inaugurou-se um espaço inédito de experimentação e bricolagem. Tratava-se, de certa forma, de «traduzir» a kizomba do português para uma língua franca. Os cursos já deviam ser leccionados em outras línguas e era preciso encontrar uma linguagem sobre a dança que falasse para todo o mundo.

Em relação ao êxito desse processo de difusão assiste-se, actualmente, a dois fenómenos. De um lado, há uma extensão da denominação «kizomba» a modalidades de danças que nas suas propriedades concretas (expressão do corpo e dispositivos coreográficos) distinguem-se sensivelmente daquilo que supomos que o leitor 
angolano reconheceria como kizomba. Do outro, assiste-se a um fenómeno de institucionalização de subgéneros que, daí em diante, seriam designados por termos a parte. Estes subgéneros - cujo nome seria mútuo dos géneros musicais aos quais a dança se adapta (nomeadamente semba e tarrachinha) - constituiriam particularizações do modo angolano de dançar em par.

Estas diferenciações parecem menos ditadas por propriedades intrínsecas à dança (elementos sobre os quais voltaremos) que por instâncias externas a dança em si.

Primeiramente, dever-se-iam uma vez mais, a uma abordagem da dança mediada pela música. Ademais, parecem adaptar-se às dinâmicas de diferenciação e auto diferenciação operantes no seio do público.

Por um lado, aquela que propomos chamar «kizomba», enquanto modo angolano de dançar em par, se multiplica em subgéneros susceptíveis de um ensino e de ocasiões festivas especificamente dedicadas. Por outro, expressões desenvolvidas no exterior, que pouco partilham com a kizomba, tais como definimos em cima, se autodesignam como «kizomba» e se servem do circuito sensacional e didáctico da kizomba (nomeadamente os festivais) para se promover e legitimar.

O segundo processo é liderado, mais ou menos conscientemente, por praticantes europeus, enquanto o primeiro é êxito de uma reflexividade sobre a dança praticada tanto por europeus quanto por angolanos. Os primeiros são por vezes, mas nem sempre, animados por uma reivindicação consciente do direito de «criar» ou de inovar, enquanto os segundos - movidos por preocupações mais puristas - são animados por um vivo interesse pelas coisas da cultura, que, concretamente, se manifesta em uma erudição musical que visa discriminar géneros e ver a sua mútua influência.

Angola, embora seja reconhecida e evocada como fonte de ori150 gem da dança está, de facto, subrepresentada. A valorização de Angola como fonte de origem anda curiosamente de mãos dadas com uma crescente subrepresentação da kizomba angolana fora de Angola.

Esta marginalização dos angolanos revela-se em várias formas. Um aspecto, já evocado, é a cada vez menor proporção de angolanos entre os agentes da difusão da kizomba, face ao crescimento do número dos agentes estrangeiros da difusão; um segundo aspecto é a dificuldade dos pares angolanos de sair de Angola e participar 
nos concursos internacionais. Esta dificuldade é imputável tanto a dificuldades logísticas como a dificuldade de obtenção dos vistos, quanto a uma falta de harmonização entre os formatos dos concurso angolano e internacional. Outro aspecto da disparidade de produção de visibilidade da parte dos dançarinos angolanos no meio internacional da kizomba é ditado pelo menor acesso por parte dos dançarinos angolanos à internet. Para muitos deles, frequentemente procedentes de meios pouco abastados, não é fácil gravar e carregar on line os próprios vídeos e introduzi-los nos circuitos de informação dos praticantes europeus. A escassa conexão dificulta igualmente a sua participação no debate sobre a kizomba que circula nas redes sociais, debate que, para o lado angolano, é em maioria representado por angolanos residentes fora do país.

De facto, o processo que se constata é que a institucionalização de um género de dança «kizomba» está acontecendo fora de Angola. A questão que será levantada toca os limites de identidade de uma prática do corpo no âmbito de um campo de transformações. Esta expansão da kizomba é na realidade um processo de extensão da denominação ou trata-se de um processo de transformação de uma mesma dança?

O nosso objecto empírico é então um corpus de danças que partilham a autodesignaçao «kizomba», de um lado, e, de danças que partilham as mesmas lógicas motoras da kizomba, embora por vezes tendam a se definir através de outros nomes mútuos aos géneros musicais, do outro.

O método que seguiremos para abordar o assunto baseia-se na descrição etnográfica de algumas variáveis da dança respectivamente em contextos angolano e europeu. Ademais, vamos abordar este campo de transformações com o intuito de explicitar as ideias subjacentes às transformações no âmbito do processo de difusão para fora de Angola. Este processo de transformação que acontece na Europa seria orientado pela ênfase e resemantização de certos traços da dança.

Algumas propriedades concretas são extrapoladas e enfatizadas pelo seu potencial de expressar e comunicar determinadas ideias. Esta transformação pressupõe uma selecção que minimiza certas propriedades da dança e, vice-versa, aumenta a importância de outros que são retidos porque considerados mais aptos a expressar uma imagem da dança. 


\section{«É consoante o toque.... ${ }^{3}$}

Na kizomba dois parceiros, supostamente um homem e uma mulher, dançam juntos por meio da conexão criada através de um abraço codificado.

Os dançarinos se deslocam no espaço executando movimentos complementares: a cada passo que o homem efectua para frente com a sua perna esquerda, corresponde um passo que a mulher efectua para atrás com a sua perna direita. Esta base de locomoção dançada é complicada por meio de passos (chamados de «passadas»). Entre estas, aquelas mais utilizadas prevêem o deslocamento lateral da linha de avançamento da parte do homem ou da mulher. Estas figuras, que no processo didáctico são chamadas «saída do homem» e «saída da mulher» tem uma importância seminal porque é através das possíveis variações na sua execução que se articulam importantes diferenças (elementos sobre o qual já voltaremos).

Uma convenção, que a kizomba compartilha com as outras danças de casal, estabelece que quem decide a direcção e a intensidade dos deslocamentos no espaço é o cavalheiro. Ao cavalheiro cabe decidir os caminhos e comunicá-los, enquanto a ela cabe perceber a indicação e seguir os caminhos indicados. O cavalheiro exerce a condução através de um «suposto» movimento de empurrar ${ }^{4}$ ou de puxar a dama, movimentos que serão por ela entendidos como uma instrução de retroceder ou de avançar.

No começo da aprendizagem, a capacitação em dança é a mesma para homens e mulheres: ambos têm que se familiarizar com as sensações de condução (activa no caso do homem, passiva no caso da mulher) e aprender os caminhos. A aprendizagem difere, no entanto, para homens e mulheres na medida em que cabe aos primeiros a escolha dos passos e da sua concatenação.

A habilidade do homem se mede pela sua criatividade, que se expressa na combinação e, eventualmente, na criação de passos e na

3 Depoimento de Mateus Pelé do Zangado, tirado do documentário de Kiluanje Liberdade (realizador) e Inês Gonçalves (produtora), A minha banda e eu (cf. LIBERDADE e GONÇALVES 2011).

4 Este movimento de segurar e empurrar a dama para convidá-la a retroceder (elemento que também é passível de se observar em algumas figuras coreográficas de rebita) constitui uma base de argumentação para quantos vejam na rebita um antepassado da kizomba. Sobre a ligação entre rebita e kizomba veja-se, por exemplo, <http://www.kizombanation.com/pt/o-que-e-kizomba> 
diversificação dos percursos. A capacidade da mulher se mede pela sua capacidade de obedecer à condução do primeiro e das suas improvisações.

Por sua vez, a apreciação da qualidade do movimento é orientada pela diferenciação de género. Desta forma, a arte de uma dançarina se mede por excelência na personalidade do seu jingado, do movimento dos seus quadris.

O cânone estético da kizomba, tal qual emerge dos usos linguísticos angolanos, refere-se a alguma relação que o dançarino consegue estabelecer com o chão: o bom dançarino é aquele que «desliza» $\mathrm{e}$ aquele que «desenha». A primeira capacidade tem a ver com uma qualidade do apoio dos pés, que prevê uma sensibilidade, uma disponibilidade, ao escorregar (qualidade que é acentuada pelo uso de calçados apropriados). A segunda é uma qualidade concernente a ocupação do espaço da pista e a figuração, a criação de figuras no chão. Assim, o bom dançarino é aquele que «desenha», que «escreve», que «risca» a pista, ao ponto de chegar a ser capaz de escrever o seu nome no chão, como se conta, aliás, do famoso dançarino luandense Mateus Pelé do Zangado.

A boa dança é aquela que realiza no chão grafismos tão sofisticados ao ponto de parecer letras. ${ }^{5} \mathrm{O}$ cavalheiro orienta a dama por meio da sua mão direita, posta no meio das costas, entre as escápulas, entre as omoplatas da dama, entenda-se. Este organiza-se na condução com a mão esquerda, que segura a mão direita da dama. A mão esquerda da dama é pousada atrás no ombro direito ou atrás do pescoço do cavalheiro. A dama pode, igualmente, apoiar a mão em cima do ombro esquerdo do cavalheiro. Neste caso, cria-se uma maior aproximação entre os parceiros ao nível do tronco e as cabeças dos dançarinos entram, quase que inevitavelmente, em contacto, a têmpora direita da dama encostando na têmpora esquerda ou na bochecha do cavalheiro.

Deste modo, o contacto das cabeças não constitui um elemento imprescindível à condução. Para que se realize uma melhor condição de transmissão da informação do dançarino para a dançarina o que, mais do que o facto de colocar a mão ou a cabeça desta ou daquela

5 A ideia segundo a qual a «dança chega a traçar letras no chão» está presente em outras manifestações performativas angolanas, tal como, por exemplo, o carnaval, onde os dançarinos visam a realização de figuras cujo entendimento pressupõe aquilo que designam por «letras». 
maneira, observa-se uma capacidade de controle e neutralização de qualquer interferência na transmissão da intenção motora (PARLEBAS 1997). Para tal, o dançarino tem que aprender a executar uma dissociação muscular e cognitiva do tronco, ${ }^{6}$ responsável pela condução da dançarina no espaço, das pernas, que desenvolvem autonomamente «truques» e variações.

A proximidade dos dançarinos, da qual depende o contacto do corpo, e que exclui as respectivas cabeças, liga-se a factores de ordem tanto técnica, quanto contextual e relacional. Pode depender da altura respectiva dos dois parceiros, que torna mais ou menos confortável o exercício para a condução de uma ou de outra posição. Pode depender do ritmo da música, sendo que, de maneira geral, as músicas mais lentas propiciam uma maior proximidade, enquanto as músicas mais rápidas resultam de mais fácil execução, mantendo uma maior distância entre os corpos. Pode, enfim, depender do grau de intimidade que os dois desejam ou conseguem criar. Ao falar de intimidade, refiro-me a uma disponibilidade mútua de um se abrir ao outro, criando o espaço e o contexto apropriado à dança.

Antes de abordar as declinações internas possíveis da dança, vale a pena acrescentar mais algumas informações sobre as nuances relacionais desta proximidade corpórea que se pode verificar na dança, porque isso permitir-nos-á desenvolver, mais adiante, algumas considerações sobre as transformações aplicadas à kizomba no exterior, a partir da selecção e da ênfase posta nalguns dos seus traços.

A fusão expressada e criada por essa maior aproximação não se associa, nem se traduz directa e necessariamente numa atracção erótica entre os parceiros. Na dança a dois, ou em casal, de expressão eminentemente social, tal qual é praticada em Angola nas festas familiares, por exemplo, é muito comum ver dançar juntas pessoas que ocupam posições de parentesco que, por axioma, excluem a atracção sexual, como mãe e filho, ou cunhado e cunhada. Esta informação, sendo banal ao ponto de parecer supérflua a quantos estejam familiarizados com o uso social da dança de casal, não nos

6 A dissociação do tronco das pernas é muscular e cognitiva e não significa uma torcedura do tronco, que seria um traço distintivo do tango (CourToIs-L'HEUREux 2012). Quando na kizomba há uma acentuação estetizante da torcedura do tronco, esse movimento parece ser ou pressupôr uma influência externa do tango. 
parece um facto para muitos estrangeiros que provêm de meios culturais diferentes, onde a dança em par já não é uma prática habitual e, por consequência, já não é aprendida através do seu uso social e recreativo, cujo objecto requer uma aprendizagem formal, para a qual o neófito é atraído através de uma representação prévia específica, veiculada pela publicidade e cujos conteúdos serão tratados mais em diante.

Vamos agora começar por abordar aquelas declinações possíveis da dança, que determinam sensíveis diferenças na sua execução, ao ponto de dar a impressão de serem danças diferentes.

A identidade da dança seria uma mesma lógica motora definida e informada pela locomoção complementar e por um pequeno conjunto de figuras, dentre as quais já foram destacadas aquelas que são didacticamente chamadas as saídas. Uma mesma dança se adapta, em modos diferentes, ao depender do variar de alguns factores.

O primeiro factor que organiza a diferença é a velocidade da música.

Na dança, como em qualquer outro tipo de acção, há movimentos mais aptos à execução rápida e há movimentos mais aptos à execução lenta. Movimentos e figuras, que são eficazes do ponto de vista estético a um ritmo mais rápido não dão certo quando executados a um ritmo mais lento, enquanto que, movimentos que dão certo quando executados a um ritmo lento, são inviáveis, ou simplesmente, esteticamente mal sucedidos, se executados num ritmo rápido.

O princípio que orienta a adaptação é que, à medida que a música se torna mais lenta, faz menos sentido executar muitas passadas. Músicas mais lentas propiciam uma interpretação com menos deslocamentos e uma menor extensão dos mesmos. Ao contrário, músicas mais rápidas inspiram nos dançarinos mais figuras e uma maior amplitude das mesmas. As músicas lentas convidam a uma maior proximidade entre os corpos dos dançarinos, enquanto que as músicas rápidas denotam a vontade de executar mais figuras e induz a manter uma maior distância entre os parceiros.

Um segundo factor de diferenciação da dança é o factor etário. A coisa que achei mais surpreendente ao chegar a Angola, onde a prática da dança não é uma prerrogativa de uma ou outra geração, como pode ser o caso onde a prática é recém importada, mas que interessa a todas as gerações, foi a diferença de interpretação da dança entre os mais velhos e os mais novos. Essa diferença pode depender tanto das mudanças das possibilidades do corpo consoante a 
idade, quanto da evolução do cânone estético da dança ao longo do tempo. Sem ainda pormenorizar muito este aspecto, o que sobressai ao primeiro olhar é uma tendência dos mais jovens a preferir músicas mais rápidas e abundar em figuras e evoluções acrobáticas, como as portées.

A par da velocidade da música, os mais velhos manifestam a sua habilidade por uma particular maneira de lidar com o chão, nomeadamente ocupar o espaço da pista pelos câmbios de direcção dos seus percursos, enquanto os mais novos o fazem através de habilidades acrobáticas.

Na dança dos mais jovens o contato com o chão é mais frequentemente interrompido e a dança se desenvolve mais na verticalidade e menos em extensão.

A dança dos mais velhos, económica no repertório de truques e acrobacias, mobiliza muito espaço, enquanto a dança dos mais jovens, económica no uso do espaço (muitos dançam quase no lugar), abunda em figuras, truques e acrobacias. Na dança dos mais velhos se observa a recorrência de algumas frases rítmicas. A dança dos mais novos tende mais frequentemente ao freestyle individual. Esta vocação mais individual da dança dos mais jovens se traduz em uma menor ênfase posta no par e no princípio de locomoção complementar.

As já mencionadas figuras correntemente nomeadas «saída do homem» e «saída da mulher» constituem um elemento técnico essencial a volta do qual se articula a diferença, pois evocam as possíveis variações da ideia de casal evocada pela dança. O grau de deslocamento e de afastamento dos parceiros, alcançado pelas saídas e a frequência do seu uso em uma dança, constituem marcadores de uma mudança da relação de casal que se quer exibir pela dança. Quando estas figuras são executadas mantendo uma proximidade a nível do tronco uma ideia de maior fusão do par é 156 sugerida. Quando o uso destas figuras é muito frequente ao longo de uma dança e/ou a sua execução comporta um maior afastamento dos parceiros, os pares da dança têm uma maior independência quanto à relação.

No primeiro caso, o agente da dança é um par, no segundo, são duas individualidades que dançam em par. Se, no primeiro caso, se procura a perfeita complementaridade, no segundo, uma perfeita complementaridade não é alcançada ou procurada. 


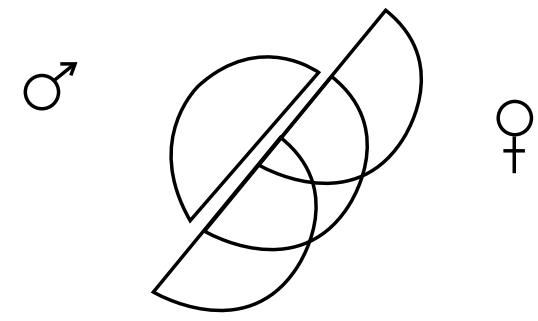

Fonte: Autor

Figura 2. No deslocamento lateral os parceiros adquirem uma posição perpendicular
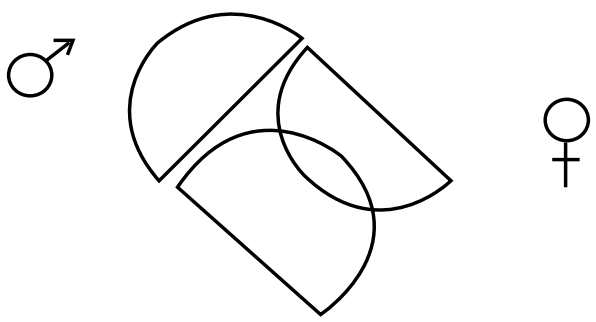

Fonte: Autor

A faixa etária dos 30 anos parece o elo de conjunção entre duas maneiras de dançar sensivelmente diferentes. Se a diferença entre as gerações deve ser atribuída à variação do cânone estético, a possibilidade de mudança das capacidades do corpo do ponto de vista fisiológico constitui uma interrogação cuja resposta só poderemos obtê-la com o passar do tempo.

Os aspectos acima enunciados, articulam a diferença entre a maneira de dançar dos mais velhos e aquela que hoje se observa dos mais novos; mostram como estas se relacionam ou se associam a uma gestão do esforço, aspecto que, segundo Laban, constitui uma das chaves analíticas fundamentais da coreografia (LABAN 1994).

As músicas lentas estimulam interpretações que requerem menos esforço. Porém, observa-se que em termos de esforço, a dança dos mais velhos é mais económica; ou melhor, o esforço é alocado de maneira diferente. Na dança dos mais velhos, a ampliação dos percursos é compensada pelo recurso a repetição de frases rítmicas 
recorrentes; enquanto que, na dança dos mais novos, o maior esforço exigido no freestyle e nos elementos acrobáticos é compensado por um encurtamento dos percursos. Por isso mesmo, não será supérfluo observar que, se de um ponto de vista o envelhecimento pode significar o progredir de uma limitação, de outro, pode representar uma acumulação de experiência que se traduz num aperfeiçoamento de algumas capacidades, nomeadamente, o da sensibilidade de condução. Consoante adoptemos, por um lado, um cânone estético de dança mais ligado ao estilo na gestão do espaço e à eficácia da conexão, ou, por outro, ao oposto, um cânone mais ligado a agilidade acrobática e a criatividade lúdica, parecer-nos-á melhor a dança dos mais velhos ou dos mais novos?

Esta diferenciação tem uma importância seminal, pois a encontramos de maneira particularmente marcada no campo europeu da kizomba. Ali, essas diferenças interpretativas (par versus soma de individualidades; passadas versus acrobacias) fixam-se em estilos por vezes em concorrência para se ver atribuída a palma da autenticidade angolana.

Um outro aspecto da diferenciação concerne a «postura social» da dança. Alguns dançarinos procuram adaptar o seu registo corpóreo a uma preocupação de distinção e de elegância. Outros, ao contrário, não exibem particular esforço para alcançar esta tensão corporal comunicando um estilo corporal mais descontraído.

Se para alguns a dança de casal é essencialmente um exercício de distinção para outros é um exercício de diversão.

Um último aspecto da manifestação da diferença é aquele que eu chamaria o «tom» emotivo da dança. Este parece se associar tanto à velocidade, quanto ao conteúdo semântico das músicas.

Antes de prosseguir este raciocínio, vale salientar que o dançarino não está, principalmente, à escuta da dimensão semântica, pois a sua escuta está focada, em primeiro lugar, em outros elementos da música, nomeadamente o ritmo, mas igualmente a melodia, especialmente se esta é previamente reconhecida. Valerá a pena observar também, para introduzir uma primeira noção comparativa, que para um dançarino não lusófono, a dimensão semântica é a menos acessível e por isso vale supôr que é ser aquela que menos influi na interpretação.

Podemos concluir afirmando que competência em dança se mede nessa capacidade de escuta múltipla. A improvisação coreográfica do bom dançarino é orientada por uma espécie de entrosamento 
espontâneo, que tem em conta o ritmo, a melodia e, enfim, este tom emotivo veiculado pela letra.

Em conformidade com a rebita e as músicas carnavalescas (RIBAS 1965), as letras dos sembas, tratam sobretudo os temas do quotidiano. O ritmo, geralmente bastante acelerado, sugere ao dançarino um tipo de interpretação em que expressa a sua habilidade pelos truques, a busca de passagens, como se estivesse encontrando soluções motoras pelos dilemas colocados, a nível semântico, pela música. Os amores narrados no semba concernem arranjos matrimoniais mal sucedidos, a degeneração dos costumes, etc.

A kizomba, género musical surgido a partir dos anos 1980, do encontro entre o zouk antilhano e a tradição local do semba (MOORMAN 2008), se distingue do semba não tanto e não só por um ritmo geralmente mais lento, mas especialmente e, sobretudo, pelas letras. Estas passam a ser preferencialmente em português (Moorman idem) e muda o conteúdo semântico.

Diferentemente do semba, em que o cantor se dirige a um terceiro ouvinte, na kizomba, o cantor dirige-se directamente a mulher desejada. Longe dos problemas práticos dos amores do semba, de traições e pedidos não merecidos, o amor cantado, já não em kimbundu, e sim em português, na kizomba, fala-se de amores românticos, emotivos, sensuais.

A combinação de desaceleração rítmica e dessa mudança de conteúdos semânticos, sugere uma execução diferente da dança, uma aproximação dos parceiros, um recuo afectivo e íntimo, em detrimento da dimensão espectacular da dança.

A medida que a música se torna mais lenta, os movimentos reduzem a sua amplitude, abdicando progressivamente a dimensão espectacular. A amplitude dos passos se reduz até que não haja mais deslocamento dos pés. A intenção motora - que surge a altura do abdómen - já não se traduz em passos, mas em simples trocas de pesos, perceptíveis ao dançarinos, mas quase escondidas aos olhos externos.

Assim como a narração do semba se dirige a um terceiro que ouve, a dança é para um terceiro ver. O discurso da kizomba, ao contrário, se dirige directamente à mulher amada. Da mesma forma, a interpretação em dança da kizomba é ligada a possibilidade de sentir, no presente da dança, as emoções que são evocadas pelo canto. É uma dança que não é para ser apreciada pelos olhos de quem a vê, mas sim pelos sentidos que quem a faz. 


\section{Explicitar a sensualidade da dança}

Vamos agrora tratar de observar as diferenças visíveis emergentes entre a maneira angolana de dançar kizomba e a maneira como esta dança se está a desenvolver na Europa.

A diferença opera sob dois pontos de vista. Mudam tanto o trabalho e a organização do corpo, quanto a maneira de combinar os passos. A lógica somática subjacente à dança é mais visível na dança aplicada ao uso social e recreativo, enquanto que a lógica coreográfica é mais claramente perceptível na dança espectáculo, por exemplo, num show ou na prestação perante um concurso. É nestes contextos que uma representação prévia da kizomba actua de maneira mais evidente, seleccionando e enfatizando traços tidos como salientes e característicos.

Antes de continuar, afigura-se-nos necessário prestar alguns esclarecimentos acerca da utilização das expressões «maneira europeia» e «maneira angolana» de dançar kizomba, dado que, em nosso entender, estas constituem categorias construtivas para a discussão analítica.

Se existe uma kizomba europeia esta apresenta-se como o fruto de um articulado aparato de cursos, concursos e de ocasiões recreativas. $\mathrm{O}$ circuito da kizomba na Europa constitui uma opção no âmbito de um vasto leque de entretenimento através da dança, presentes no mercado recreativo. Ao se introduzir neste circuito, o aprendiz exerceu uma escolha prévia que o situa num campo onde cada elemento representa um marcador de pertenças socioculturais específicas. Essa escolha prévia é orientada por alguns pressupostos e expectativas concernentes a dança de casal e, mais em particular, àquela em questão.

Ao contrário, a kizomba em Angola representa o modo local de dançar em par, ou em casal, num contexto em que a dança constitui uma modalidade recreativa altamente difundida, ou, parafraseando Óscar Ribas, representa, propriamente, uma modalidade recreativa por excelência (RIBAs 1965).

Assim, quando se fala de diferenças entre uma e outra modalidade, estas devem ser entendidas à luz destas diferentes modalidades de socialização da dança. Transformar-se mum dançarino de kizomba não é o mesmo em Angola e na Europa. Em Angola, trata-se de uma capacitação para a dança em par; na Europa, trata-se da aquisição de um específico código de dança em par no meio, no ambiente de outras danças. As diferenças concretas que se observam nas duas 
versões da dança, dependem desse diferente modelo de aculturação corpórea cultivada pela dança.

Ademais, a redução da variação empírica presente nos dois campos a dois modelos poderá parecer uma simplificação arbitrária. Já abordamos rapidamente os factores que diferenciam a maneira angolana de dançar. Em Angola, o principal elemento que diferencia o campo da dança é o factor etário. Na Europa também já existem várias maneiras de dançar kizomba. À luz destas considerações, reconduzir a complexidade empírica dos dois campos a dois modelos parece indevidamente redutor. Cientes da complexidade do plano empírico, estas duas expressões serão utilizadas pelo seu valor heurístico comparativo, com o intuito de focar as concepções que orientam a criação da diferença.

Assim, parece-nos que é neste último aspecto da questão, concernente os dispositivos subjacentes à criação da dança, que uma comparação entre uma maneira supostamente angolana e uma maneira supostamente europeia de dançar kizomba, que nos chegam mais elementos. E é nesta intencionalidade coreográfica, que mais claramente se afirma a diferença.

Sob esta definição estão sendo abarcados dois fenómenos muito diferentes, para não dizer opostos: de um lado, a inspiração espontânea e instantânea de aplicar e combinar figuras num dado momento da música; do outro, um projecto de show previamente meditado e ensaiado.

A diferença entre a maneira angolana e a maneira europeia de fazer kizomba, que no contexto de uma prestação se manifesta na sua máxima amplitude, surge, no entanto, aquém do show, no seu uso recreativo e nas condições da sua aprendizagem.

A maneira angolana de dançar é sempre improvisada e é orientada por um entrosamento espontâneo. O que é memorizado, ou melhor, incorporado, é a figura, ou, no máximo, a concatenação de figuras. O que deve ser testado pelo treino é a viabilidade de concatenar determinados passos e figuras. No quadro de um show uma coreografia emerge de uma capacidade de improvisação bem treinada pela fina incorporação de cada passo, movimento, truque. Esta adequação espontânea selecciona as figuras em adaptação às propriedades da música. A competência mede-se nesta adaptação.

A adequação entre a acção de dança e a dimensão semântica de uma música é um critério estético mais abrangente, que orienta a criação em outras manifestações performativas angolanas, tal como, 
por exemplo, no carnaval. ${ }^{7}$ Da mesma forma, na dança de casal, observa-se que esta é criada na hora, manifestando-se uma particular interpretação improvisada.

Vamos agora nos voltar para a Europa. A maneira europeia de dançar kizomba, tanto no uso recreativo, quanto no uso espectáculo e competição, tem por fio condutor a explicitação da sensualidade que lhe é atribuída. Aqui, a kizomba é vista e imaginada como um género de dança lenta. Esta suposta lentidão que lhe é intrínseca e que caracterizaria o seu género, vai de par com a sensualidade que lhe é atribuída. Tem que se ter o tempo de sentir.

No contexto de um show, a intenção coreográfica opera no sentido de visualizar, no sentido de tornar visível, a experiência sensual que - na base desta representação - o dançarino é suposto sentir na dança.

Mas antes de voltar à dimensão coreográfica dessa distinção, vamos nos ater sobre os aspectos do movimento.

\section{Da jinga para a «afro-jinga $»^{8}$}

Convencionalmente na kizomba, a parte da criação da dança cabe ao cavalheiro. Neste trabalho, o cavalheiro pode-se inspirar em vários elementos da música, privilegiando o ritmo ou a melodia para criar frases.

O esforço da dama é mais regular e é constituído por movimentos que tendem a acompanhar a pulsação. Para simplificar essa ideia, a dançarina anda. Um atraente movimento de dança aparenta a sua execução na forma de uma linda andadura. Como já Marcel Mauss

7 No concurso carnavalesco, o entrosamento, a coerência, a adaptação constituem importantes parâmetros de avaliação no âmbito de um concurso (MINIsTÉRIO DA CULTURA 2013: 21 e segs.).

8 Em contextos pós-esclavagistas e pós-coloniais a África constitui um reservatório simbólico para a construção de identidades negras. A literatura sobre este assunto abunda a partir do texto seminal de Paul Gilroy (Gilroy 1993). No ensaio «Da África ao Afro», a que se faz alusão através deste titulo, Lívio Sansone descreve as dinâmicas através das quais representações sobre a África se tornam marcadoras de específicas de subculturas urbanas (SANSONE 2004). Na França - onde a preocupação com uma kizomba que fosse mais autenticamente africana, deu vida a um sub-circuito que se destaca do mais abrangente circuito europeu da kizomba - surgiram cursos de «afro-jinga» em substituição aos mais genéricos cursos de lady styling. 
reconhecia, a andadura não é, porém, um dado natural, mas o resultado de uma construção cultural (MAUss 1936).

Na kizomba europeia, o movimento da dançarina é objecto de uma instrução específica, veiculada por cursos de «lady styling», ou, mais recentemente, de «afro-jinga». Os movimentos que fazem objecto desta específica didáctica visam acentuar a mobilidade dos quadris. A intenção dessa aprendizagem é materializar, através da capacitação de uma área anatómica, um registo de sedução. O que se movimenta é um corpo activamente disciplinado por essa educação, quase rígido, que se expressa em longos passos. O joelho é hiperextenso e a movimentação dos tornozelos é seriamente limitada pelo uso sistemático de talões. Por causa dessa limitação, imposta aos tornozelos e aos joelhos (intencional no caso dos joelhos, determinada pelo calçado, no caso das canelas) as ancas movimentam-se por efeito de uma activação focada, intencionalmente procurada. Enfim, se a kizomba é uma dança sensual, os quadris devem, têm que se mexer!

Na kizomba angolana, cuja prática é recreativa, os passos são mais curtos. $\mathrm{O}$ balanço dos quadris não é obtido através de um movimento intencional, mas resulta naturalmente de cada passo. Na ausência de qualquer focalização proscritiva, que impeça aos joelhos o seu natural movimento de amortização, a percussão do pé no chão traduz-se por um balanceio dos quadris. Enquanto na maneira europeia, o movimento das ancas é obtido por uma dupla focalização proscritiva nos joelhos e prescritiva nas ancas, na maneira angolana o movimento é obtido por uma ausência de focalização proscritivas.

Na modalidade angolana, o aperfeiçoamento da dança não visa a busca activa de mais movimento, mas a remoção de todo obstáculo corpóreo mecânico, que impeça a sua natural manifestação. Na modalidade europeia tende-se a buscar o movimento; na modalidade angolana, trata-se de deixar o movimento acontecer e isso a partir do passo.

É nesse espírito de remoção de todo obstáculo ao movimento, que se inscreve a estratégia da dançarina social angolana (da dançarina não profissional, entenda-se), de levar consigo, em ocasião de celebrações, um par de sabrinas para a dança. O sapato com salto é para a missa, as sabrinas, sapato da locomoção e do dia dia, são para a boda.

Foi com muita admiração que as minhas amigas angolanas me viram dançar com salto alto. Foi com surpresa ainda maior, que descobriram que na Europa as dançarinas de kizomba vão para a farra com sapatos com salto nas suas pastas. Na falta de um tipo de sapato mais apto ou adaptado, a capacidade de dançar de salto é admirada pelas dançarinas 
angolanas; mas chegar à farra com sapatos rasteiros, para depois calçar sapatos com saltos para dançar, era mesmo algo estranho.

Tanto na noção angolana, quanto na europeia, tem-se a ideia que um tipo específico de sapato proporciona o aperfeiçoamento do gesto dançado. Em ambos os casos, entendem que esse tipo particular de calçado se associaria a um tipo específico de jingado. A opção, no entanto, parece-nos que tende mais para o sentido oposto. Na maneira angolana, a preferência para o um tipo de sapato raso, útil ao uso quotidiano, representa a remoção de uma inibição mecânica do movimento. Com esse sapato, as articulações são livres de transmitir a impulsão vertical devolvida pela percussão dos pés no chão.

A preferência para o sapato com salto na kizomba europeia pode ser visto sob várias perspectivas. Pode-se associar a importação na kizomba de passos próprio ao tango, onde este calçado proporcionaria uma maior facilidade para certas figuras. ${ }^{9} \mathrm{O}$ que concretamente se constata é que o uso deste tipo de sapato convida a um tipo particular de movimento disciplinável, intencionalmente buscado. No entanto, pode-se também pensar que o uso deste calçado se inscreva nessa busca de sedução pela dança. Esse objecto seria um reforço dessa mensagem visada pelo movimento.

\section{Do trabalho do homem}

Da modalidade angolana para a modalidade europeia de dançar kizomba, a dança das mulheres difere pelo tipo de movimento procurado; a dança dos homens difere pelo tipo de movimento objectivado e pela intencionalidade coreográfica que preside a concatenação de figuras, o uso de truques, etc., etc.

Seriam as diferenças entre a dança kizomba praticada pelos dançarinos angolanos e pelos dançarinos europeus, inteligíveis em termos de qualidade, consequência da menor aculturação dos dançarinos europeus neste género de dança, ${ }^{\mathbf{1 0}}$ ou as diferenças estariam

9 Tratando-se de um tango, a efectivação de algumas figuras da dança seria presumivelmente facilitada pelos saltos do calçado (COURTOIs-L'HEureux 2012).

10 Segundo Michael Houseman, a dança seria uma modalidade de acção intrinsecamente quantitativa; isso significa que é mais dança aquela que é tida como a boa dança (HousEman 2002). Esta reflexão sobre a dança pode ser testada na definição do género de dança. Assim, no nosso caso seria mais kizomba e, 
no movimento e nas tendências coreográficas, o resultado da busca intencional por uma expressão que seja representativa de uma ideia de kizomba? A kizomba criada na Europa é uma dança mal sucedida ou é uma outra dança, que vem sendo criada e designada pelo nome de kizomba?

Se há diferenças entre uma e outra, vamos então analisar essas diferenças.

Uma das características que se observa em muitos dançarinos angolanos de kizomba, está ligado à sua postura, que é se apresenta ligeiramente reclinável, encurvado. O homem se inclina sobre a mulher. A sua cabeça é inclinada para baixo e o seu olhar, que os olhos estejam abertos ou fechados, tendem a se inclinar para o chão, expressão que evoca uma atitude ligada à reflexão e ao pensamento. Mostra-se, possivelmente, como uma certa introversão da sua concentração ou timidez.

Figura 3. Exemplo de postura de homem na kizomba angolana

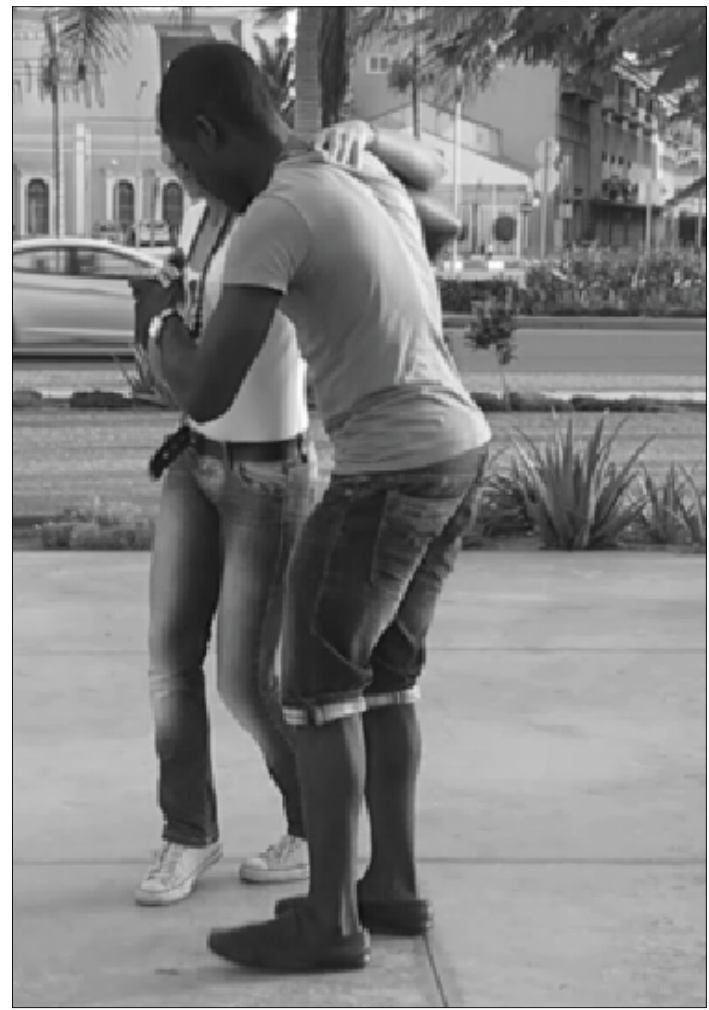

Fonte: Autora

certamente, da boa kizomba. No entanto, só a descrição detalhada dos critérios locais de apreciação nos vai permitir que se saia da tautologia. 
Esta espécie de inclinação, que sugere momento de reflexão, parece uma postura característica bem peculiar de muitos dançarinos angolanos, que não pode deixar de evocar o motivo da notável estatueta angolana, que ficou mais conhecida por «o pensador». A ligeira inclinação para frente do tronco, ao nível do qual se realiza a conexão, é contrabalançada por um ligeiro recuo das nádegas, quase como um código implícito de gentileza, como que, quase a querer esclarecer qualquer equívoco diante da parceira de dança.

Qualquer que seja a estatura respectiva do homem ou da mulher, estes estabelecem soluções posturais (por exemplo, através de uma ligeira dobragem dos joelhos), que garantem um equilíbrio relativamente a uma distância sobre a parte baixa do abdómen. Este modelo de segmentação do corpo parece bem característico da postura dos pares de dança angolanos.

Figura 4. Exemplo de combinação postural dos dançarinos na kizomba angolana

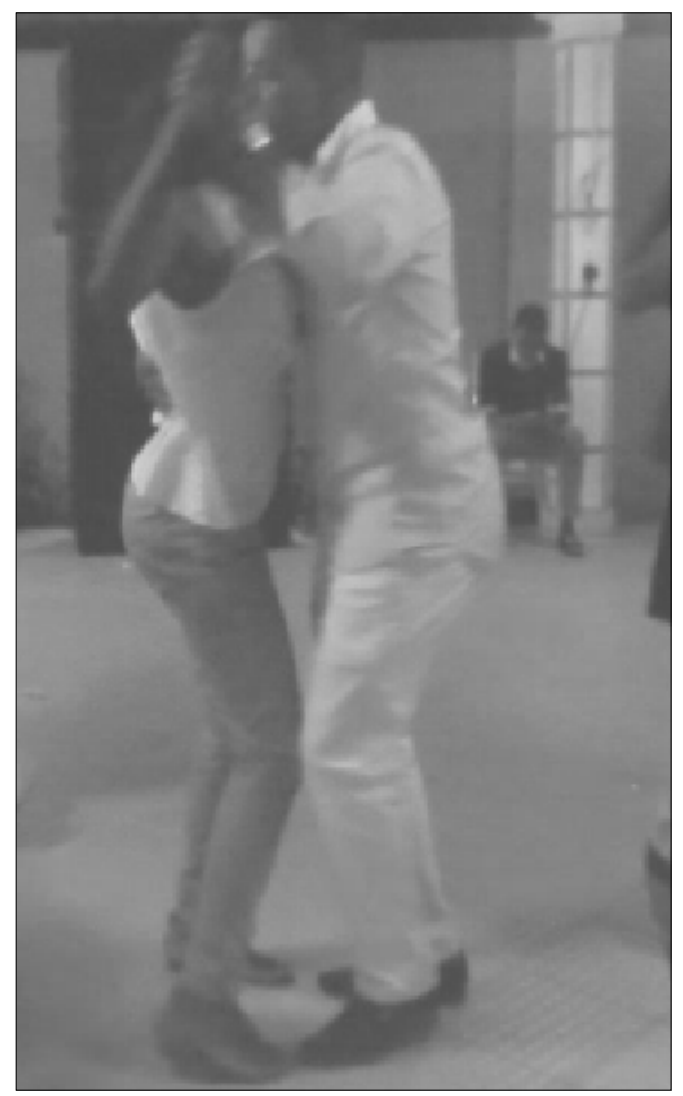

Fonte: Autora 
Já a kizomba europeia não nos parece marcada pelas mesmas lógicas socioposturais. Mais frequentemente, o dançarino europeu encontra o seu equilíbrio através de uma postura mais recta, onde se constata um alinhamento vertical da parte baixa do abdómen à parte alta do tronco e aos pés. Esta postura mais recta traduz-se numa aproximação da parte baixa do abdómen à dançarina. A esta aproximação a dançarina reage através de uma anteversão do quadril ou um distanciamento dos pés e uma inclinação do busto.

Figura 5. Transformação da postura do homem, que olha da esquerda para direita

(exemplo 1)

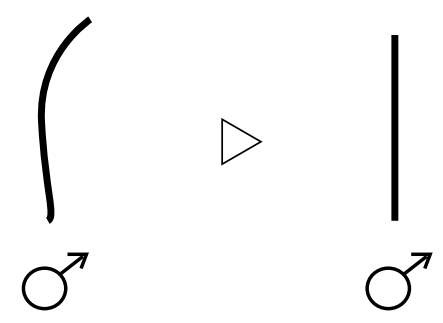

Fonte: Autora

Ou

Figura 6. Transformação da postura do homem vista do lado direito: o seu olhar é direcionado para a direita (exemplo 2)
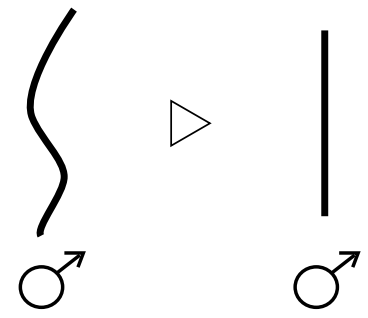

Fonte: Autora

Esta aproximação, ou melhor, a ausência de um equilíbrio postural, que preveja o afastamento da parte baixa do abdómen da parte do dançarino, encaixa-se apropriadamente com a erotização da dança na Europa. Na geografia simbólica do corpo, os umbigos têm que estar em contacto. 
A anteversão do quadril da parte da dançarina, que nada mais é que uma resposta postural e socio-postural instintiva, se torna um cânone estético de dança a ser seguido. O mesmo vale para o afastamento dos pés e a inclinação para frente. Desta maneira, haveriam recombinações do equilíbrio do par que, estilizadas, apareceriam mais ou menos da forma que segue.

Figura 7. Recombinações do equilíbrio do par visto de lado: os parceiros olham um para o outro

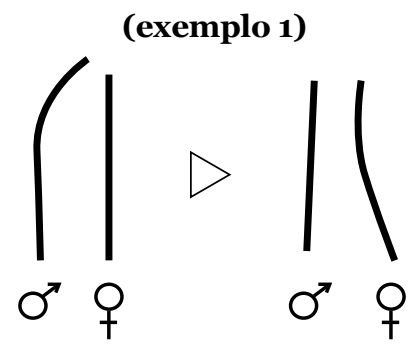

Fonte: Autora

Ou

Figura 8. Recombinações do equilíbrio do par vista de lado: os parceiros olham um para o outro (exemplo 2)

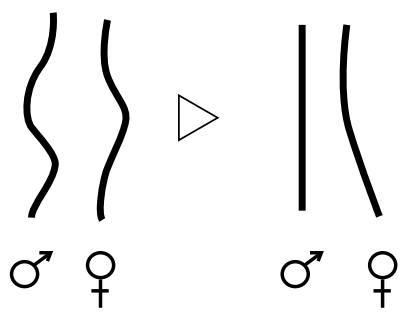

Fonte: Autora

168

De um lado, teríamos uma combinação que tende a ser simétrica; do outro, a uma postura recta do homem corresponde uma inclinação para frente da mulher, como se observa, por exemplo, no tango. 
Figura 9. Transformação da postura da mulher vista do lado esquerdo: o olhar dela está direccionado à esquerda (exemplo 1)

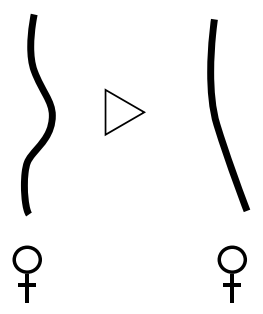

Fonte: Autora

Esta diferença tem, igualmente, um efeito na distância no nível dos pés, que é maior no segundo caso, e obriga a dançarina a efectuar passos mais longos, um elemento que, já foi mencionado anteriormente.

\section{Acerca dos aspectos coreográficos}

Na maneira europeia lança-se mão a blocagens, pausas da acção, como que a expressar uma hesitação, uma paixão interior. O que está em jogo nestes dispositivos coreográficos é uma espécie de estetização de uma incerteza, de uma dúvida, de uma laceração moral, de uma tentação que seria experienciada pela dança.

Da modalidade angolana para a modalidade europeia, uma reconfiguração da relação entre os membros do par é encenada. Essa mudança da qualidade da relação em causa é expressada por meio de dispositivos técnicos. O fluxo - «corrente», na modalidade angolana - é «interrompido» e a acção - «contínua», na modalidade angolana - torna-se «sacudida» (LABAN 1994: 80). Um caso mais extremo desta reorganização da temporalidade pela ênfase posta nas pausas é representado pela modalidade designada 2.o. Nesta versão digital ${ }^{11} \mathrm{a}$ dança reduz-se a uma sequência de posições. ${ }^{12}$

11 [Kizomba (?)] 2.0 é a denominação que alguns dançarinos franceses adoptaram em 2014 para designar e caracterizar a versão de kizomba (?) que desenvolveram e que hoje ensinam. Esta definição brilhante, concatenada à linguagem dos smartphones e dos tablets, designaria uma versão sucessiva, uma evolução, da velha kizomba, breve, uma sua versão 2.0.

12 Cf. <https://www.youtube.com/watch?v=2fUxowBdQ8U> 
Nestas hesitações da parte do homem, a mulher tem mais tempo para expressar uma resposta de um tipo diferente da obediência face a um comando claro. A condução tende a se tornar um convite e a mulher pode reagir com um contra-movimento. Nesse aspecto, a vertente europeia da kizomba, que estamos empenhados em descrever, teria um ponto de convergência com o tango, onde é encenado um combate de intenções entre o homem e a mulher (CourToIs-L'HEUREUX 2012). Essa batalha de intenções, primeiramente no seio do homem, se expressa em bloqueios, pausas, sacudimentos e contra movimentos.

Nesta modalidade de kizomba desenvolvida na Europa, o movimento de quadris da dançarina, não é o natural balanço lateral consequente ao passo, mas sim, uma ondulação sagital da coluna e de um acentuado movimento de frente para trás da bacia, accionado intencionalmente. Através desta ondulação sagital - que lembra ao de uma serpente, símbolo claramente evocador na tradição judaico-cristã - a dançarina expressa o seu poder de sedução diante do dançarino e do público.

As modalidades angolana e europeia de kizomba se diferenciam não somente pela diferença das relações postas em evidência no seio do par, mas, igualmente, diante do espectador. A kizomba à maneira angolana é, de um lado, uma dança informada pela ostentação de habilidade (aspecto que se expressa na proliferação de truque), e, por outro, pela ostentação de classe (que se expressa na postura e na complicação competitiva dos caminhos).

Logo, da modalidade angolana à modalidade europeia, realiza-se uma reconfiguração do quadro relacional que está em jogo na dança: dentro do par e do par para fora deste, diante do potencial espectador.

\section{Ser o melhor em kizomba: A maka do semba}

«Com o regulamento anterior, um francês nunca poderia ganhar» - me explicou um professor de kizomba na França. E, de facto, foi em 2014, depois que se estabeleceram algumas modificações do regulamento, que um par francês, enfim, logrou vencer o campeonato internacional de kizomba.

Essa vitória ocorreu pela ausência do par angolano, que não conseguiu viajar para Milão, onde, pela primeira vez, acontecia o concurso. 
Porém, mesmo que tivesse podido viajar, o par angolano ter-se-ia colocado em face de um grande dilema de interpretação, que poderia colocá-lo em risco de não vencer a competição.

O campeonato internacional prevê duas provas. A primeira, está sujeita a um tema obrigatório, que é denominado «Improvisão de Kizomba». Nela, os pares têm que improvisar sobre um tema a escolha da organização. A segunda, constitui um tema livre, que é denominado «Kizomba show», e sujeita-se a escolha de cada concorrente. Do total das duas provas, observa-se que a segunda prova, tendo a duração de 1' e 30", nela estão misturados «vários tipos de kizomba» (dança lenta, rápida e tarraxinha). Nesse minuto e meio, os concorrentes «não podem fazer nada que não seja kizomba». Ademais, os 30" restantes, são destinados a uma mistura de «outros ritmos africanos», tais como, por exemplo, a «Rebita (Angola), a marrabenta (Moçambique), o ussua (São Tomé), a coladera (Cabo Verde), o Zouk, ${ }^{13}$ Funaná e o Semba, ou ainda um outro estilo de dança africano». Observa-se que na prova de «Kizomba show», os pares têm obrigatoriamente que executar uma coreografia previamente preparada. O tema livre conta 40\%, e o kizomba show conta pelos $60 \% .^{14}$ Os «outros ritmos africanos», apontados como o repertório musical para criar um show de kizomba - segundo um processo criativo explicitamente voltado para a bricolagem dos géneros - estão em maioria, sendo a kizomba susceptível de não ser dançada, e tem como se viu, como único ponto comum o facto de serem todas originários de ex-colónias portuguesas.

Estas instruções para os concorrentes, nos parecem estar mais guiadas por uma inspiração culturalista, do que por um critério estritamente técnico. Nesta galeria luso-tropicalista, o Semba figura assim no meio de «outros ritmos africanos». Embora não seja explicitamente dito, estas instruções músico-culturológicas para os dançarinos, visam institucionalizar no nível da dança, uma suposta diferença entre Kizomba e Semba, e uma autonomização da primeira em relação a segunda. Enfim, a kizomba - na sua vertente espectacular - seria intrinsecamente enformada por esta bricolagem dos géneros.

Em 2013, as revisões efectuadas ao Regulamento de 2012, foram motivadas pelo propósito de «uniformizar e tornar mais justa a

\footnotetext{
13 Seria o Zouk um ritmo africano?

14 <http://www.africadancar.com>
} 
competição, permitindo que todos os concorrentes estejam, no máximo possível, em pé de igualdade». ${ }^{\mathbf{1 5}}$

As correcções e revisões do regulamento visavam formatar o concurso adaptando-o à kizomba, tal qual ela surge do aparato didáctico que sustenta a sua difusão na Europa. Da mesma forma, adoptava, adaptava e institucionalizava a divisão em subgéneros que, no seio da didáctica, são propostos como distintos. Assim, era necessário reformular as regras do concurso de modo a favorecer a vitória de quem aprende através desse aparato didáctico.

O problema estava em gestação há tempo e se tinha acentuado em 2012 quando um par angolano ganhou de maneira controversa. Naquele ano, a primeira prova - o tema de improvisação do kizomba - foi um semba igual para todos os concorrentes. A segunda prova previa, obrigatoriamente, 1' e 30" de kizomba, mais os 30" de outros ritmos africanos à escolha do concorrente.

Na segunda prova - um «tema livre de kizomba show» — os concorrentes europeus montaram coreografias previamente memorizadas e ensaiadas, ao som de mixagens de vários géneros musicais, dentre os quais o mais utilizado foi o afro-house.

O par angolano não mixou a música e dançou uma kizomba angolana de maneira improvisada, executando de facto uma dança muito parecida a da primeira prova. Diferentemente dos concorrentes europeus, que vestiram um traje artístico ligado à ideia coreográfica que queriam sugerir, vestiu roupa burguesa elegante. Nos primeiros 10" encenou a aproximação do par e no restante do tempo dançaram como teriam dançado socialmente uma música daquelas rotações por minuto, sem elementos técnicos espetaculares. O par angolano propôs, no contexto do concurso, a dança que teriam executado numa festa. E venceu!

Em perfeita boa fé, os vencedores desconheciam a diferença, de um lado, entre «dançar kizomba improvisação» e «dançar kizomba 172 show». Show, a rigor de lógica, seria dançar mais, mas não diferente. Da mesma forma, haveria mais do que um género de dança kizomba, a depender das rotações por minuto da música.

Em 2014, se o par angolano, escolhido para representar Angola no campeonato internacional, tivesse conseguido viajar, encontrar-se-ia numa dificuldade ainda maior porque, entretanto, a linha adoptada

$\mathbf{1 5}<$ http://www.africadancar.com> 
pela organização foi reduzir o lugar do semba, como tema obrigatório, em prol de músicas cada vez mais lentas.

Os pares angolanos são seleccionados num casting de «dança kizomba/semba». Em 2014, a competição previa uma única prova em que os pares tinham que improvisar ao som de semba, bastante sossegado, que era igual para todos os concorrentes. Haveria então uma flagrante discrepância entre o formato do concurso angolano e o formato internacional e os dois formatos respondiam a diferentes ideias de desempenho em kizomba.

Se o par angolano tivesse conseguido viajar, como teria então lidado com uma música caracterizada por um número de rotações por minuto muito inferiores aquele que naturalmente teriam preferido para um show? Mas, em geral, o que teria a mostrar com uma música tão lenta?... Qual teria sido a compreensão geral de dançar em público uma dança em que nada há a mostrar?...

O que estava em jogo nas negociações que levaram à revisão do seu regulamento era a institucionalização da kizomba à maneira europeia, como um género de dança diferente do semba. A consolidação de um género de dança kizomba supostamente diferente de um género de dança semba andou sendo suportada pelas mudanças do regulamento e das actuações do mesmo, em detrimento da maneira angolana de dançar e em prol da europeia.

Se o contexto show opera no sentido de exagerar algumas propriedades tidas como específicas da dança em questão, a maneira angolana e a maneira europeia de abordar a kizomba parecem orientadas por ideologias diferentes. As escolhas coreográficas emergentes destas duas abordagens diferem ao ponto de dar vida a danças a primeira vista diferentes.

Na maneira angolana, a diferença entre a vertente social e a vertente espectacular é observada mais numa alteração da quantidade de alguns elementos (intensidade do engajamento na dança; frequência das figuras), que numa alteração da qualidade, no sentido da modalidade. Fazer um show de dança é dançar mais, com mais elementos, mas não é dançar outra coisa. ${ }^{\mathbf{1 6}}$

\footnotetext{
${ }^{16}$ Uma outra maneira de tornar a dança espectacular, em continuidade com outras manifestações músico-teatrais como o carnaval, é o recurso a particulares sketch tirados do quotidiano. No casting para o concurso angolano de Kizomba 2014, por exemplo, um concorrente efectuou um pequeno sketch em que a dançarina, avançando de joelhos, fingia estar possuída, enquanto o dançarino, tirando do seu bolso uma bíblia, imitou em dança a postura de um pastor evangélico tentando exorcizá-la.
} 
A kizomba show à maneira angolana é uma dança de ostentação de habilidade, a kizomba show à maneira europeia é uma dança de ostentação da sensualidade atribuída ao género kizomba.

Se, segundo um amigo angolano, tarrachinha é aquele género de música que se você dançar com passadas passa por burro na pista, $o$ fio condutor da kizomba europeia é, ao contrário, tornar espectacular em dança lenta. Na maneira europeia de coreografar a kizomba, o objectivo é a visualização da sensualidade que é atribuída à dança. Este objectivo é obtido por alguns dispositivos técnicos, tais como a acentuação de pausas e suspensões que evocam uma tensão.

\section{Conclusão}

O termo kimbundu «kizomba» é um nome genérico que significa a «festa», «dança», «festa dançante» ou, em alguns contextos específicos, ainda hoje caracterizados pelo uso corrente do kimbundu, «a agremiação de dança». No português corrente, o termo kizomba designa, no entanto, um género não só de música, mas também de dança de casal.

Quando e como o termo kimbundu genérico passa a ser nome próprio da dança de casal é uma questão a ser pesquisada em termos etno-históricos. Uma explicação corrente faz derivar a kizomba, enquanto género de dança da «massemba», dança hoje conhecida pelo nome português de «rebita», em que dançarinos e dançarinas em número par dançam em preparação do elemento central: a «semba», «o toque de umbigos», a «umbingada».

Estas explicações, que defendem a continuidade evolutiva entre a «rebita» e a kizomba, não parece sublinhar devidamente a radical diferença socio-motora: a «rebita» é uma dança em roda em que o par se faz, enquanto na kizomba sem par não há dança. Na primeira, a dança ocorre sempre tendo em preparação o toque do umbigo, espetacular e instantâneo; na segunda, o contacto contínuo e permanente «dos umbigos» constitui o preliminar da dança.

A expressão de uma específica qualidade do par é o fio condutor da kizomba tanto na forma que é praticada em Angola, como na versão exportada. Para entender as ideias que orientam as transformações ocorridas, procuramos fazer uma etnografia da kizomba tal qual ela é dançada em Angola, para depois nos focalizarmos na maneira como ela é reinterpretada na Europa. O quadro etnográfico diante do qual 
nos encontramos é, de um lado, um conjunto de danças caracterizadas por núcleo comum, definido por uma mesma lógica motora, baseada na locomoção complementar e um restrito número de figuras, dentre as quais se destacam por importância aquelas que são convencionalmente chamadas de saídas.

A transformação é orientada pela amplificação de algumas propriedades que são atribuídas à kizomba. Mais em particular chegamos a argumentar a ideia que na kizomba europeia visa-se tornar visível uma experiência sensual, em última instância alusiva ao erotismo, que é supostamente vivida através da dança pelo contacto com um outro corpo e pelo facto de se movimentar ritmicamente juntos.

A representação da kizomba na Europa, que orienta estas suas alterações, coloca-a fundamentalmente como uma dança lenta. Esta representação do género de dança como associado à velocidade do movimento consolida a crença que a kizomba seja um género de dança diferente, nomeadamente, daquela que seria um género de dança semba. Ao contrário, $\mathrm{Na}$ base da etnografia da prática da dança em Angola, propomos a adopção do termo kizomba para designar, de maneira mais abrangente, a maneira angolana de dançar em par (em casal) e defendemos a ideia que a competência da kizomba se mediria numa capacidade de adequação espontânea e instantânea da acção de dança com o género musical de acompanhamento, entendido como combinação específica e característica de ritmo, padrões melódicos e registo das letras.

Ademais, esta lentidão atribuída à kizomba na concepção europeia é a propriedade que mais expressaria a sua supostamente intrínseca e característica sensualidade. Essa desaceleração do movimento dançado, que caracterizaria a interpretação europeia da kizomba, ofereceriam aos dançarinos o tempo de ser afectado pelo contato com outro corpo, pelo movimento rítmico e, através destes, com a sua própria sensualidade, entendida como atenção reflexiva aos sentidos que estão sendo solicitados pela acção de dança. A visão da kizomba como género de dança se associaria a este particular «tom emotivo», veiculado pelo tipo de letra da música (no limite, abertamente erótico) que funcionariam - quando entendidos - como legenda da experiência vivida pela dança.

Esta construção da kizomba como dança sensual, ou, mais especificadamente erótica, se expressa através de elementos técnicos obtidos por invenção ou acentuação, que distinguem a kizomba europeia da angolana, como, por exemplo, o recurso insistente a ondulações 
sagitais intencionais da coluna e marcadas anteversões rítmicas da bacia. Esta tensão sensual (isto é, esta atenção às respostas do sentidos) se expressa igualmente em outros aspectos, como uma reorganização do fluxo. O ritmo regular do movimento perde importância em prol de pausas, que seriam expressivas desta turbação interior. As pausas seriam a expressão eminente deste afecto emergente.

Em algumas evoluções mais extremas de kizomba surgidas na França, a dança nada mais é que uma sequência de posições, atingidas através de movimentos sacudidos. A dança se torna assim digital, daí a recepção do nome altamente significativo de 2.0. Nesta conformidade, esta ideologia europeia da kizomba seria particularmente evidente no contexto espectáculo, onde as coreografias são construídas com o intuito de tornar visível essa «emoção».

\section{Referências bibliográficas}

Assis Júnior António de

[s.d.], Dicionário kimbundu-português. Linguístico, botânico, histórico e corográfico, seguido de um índice alfabético dos nomes próprios. Luanda, Edição de Argente, Santos \& C. ${ }^{\text {a }}$, Lda.

CARNAVAL

2013, Carnaval. Revista Anual do Ministério da Cultura (Luanda), Ano 10, n. ${ }^{\circ}$ 9, pp. 1-50.

Courtois-L'Heureux Fleur

2012 «Bon pied, bon oeil!» Expériences fétichistes de l'objet à l'épreuve de la danse», in Loïc Nicolas e Aline Wiame (dir.), «Objets qui nous hantent, objets qui nous tentent. Nouvelles technologies, arts, philosophie», L’Année Mosaïque, n. ${ }^{\circ}$ 1. Bruxelles, Éditions Modulaires Européennes, pp. 71-95.

Gilroy Paul

1993, The Black Atlantic. Modernity and double consciousness. Londres e New York, Verso.

Houseman Michael

2003, «Vers un modèle anthropologique de la pratique psychothérapeutique», Thérapie Familiale, vol. 24, n. ${ }^{\circ}$ 3, pp. 289-312.

LABAN Rudolf

1994, La maîtrise du mouvement. Paris, Actes du Sud.

Mauss Marcel

1936, «Les techniques du corps», Journal de Psychologie, XXXII, 
n. ${ }^{\circ}$ 3-4, 15 mars-15 avril. pp. 271-293. Communication présentée a la Société de Psychologie le 17 mai 1934.

1983 (8. ${ }^{\text {a }}$ edição), «Les techniques du corp», in Marcel Mauss, Sociologie et Anthropologie, précédé d'une Introduction à l'oeuvre de Marcel Mauss, par Claude Lévi-Strauss. Paris, Presses Universitaires de France, pp. 368-386 [«Quadrige»; 58].

MOORMAn Marissa J.

2008, Intonation: A social history of Music and Nation in Luanda, Angola, from 1945 to recent times. Ohio, Ohio University Press [«New African Histories»].

Negro Francesca

[inédito] Maybe you are not born in Africa, but a little bit of Africa is born in you.

PARLEBAS Pierre

1997, Giochi e sport. Corpo, comunicazione e creatività ludica. Torino, Il Capitello.

RiBas Óscar

1965, Izomba. Associativismo e recreio. Luanda, Tipografia Angolana.

SANSONE Livio

2004, Negritude sem etnicidade. O local e o global nas relações raciais. Culturas e identidades negras do Brasil. Salvador, EDUFBA; Rio de Janeiro, Pallas.

\section{Filmografia}

LIBERDADE Kiluanje e GonÇALVEs Inês

2011, A minha banda e eu (Filme documentário de 90’), realizado por Kiluanje Liberdade. Lisboa, Filmes do Tejo II. Disponível em <icateca.ica-ip/filme/A+MINHA+BANDA+E+EU/1800>

\section{Vídeos}

<https://www.youtube.com/watch?v=UhgoG9MWzS8>

$<$ https://www.youtube.com/watch?v=95ZART15w20 >

$<$ https://www.youtube.com/watch?v=p4DCep44dT8>

$<$ https://www.youtube.com/watch?v=unX95S8viEw >

<https://www.youtube.com/watch?v=2fUxowBdQ8U> 
Title: To see the «emotion». Angola's kizomba to the world

\begin{abstract}
With this work I intend to study the international diffusion of a type of couple dance of Angolan origin known as kizomba, as well as its consequent transformations. The specific characteristics of this type of dance are being codified and institutionalized in Europe through teaching and international competition. These procedures (classes and dance competitions) are based on some specific properties of this dance, which I try to analyze in this article. In proposing a definition of kizomba as a dance type, I also intend to demonstrate how its contemporary international version rests primarily on the idea of sensuality. This quality, which is attributed to kizomba and which circumscribes it in specific choreographic movements and choices, is undoubtedly the fundamental emphasis of the European version.

Keywords: Angola, kizomba, semba, rivet, zouk, dances, choreography, choreography, ethnographic research, visual anthropology, affections, emotion, teaching, competition, transnationalization, blackness, Mateus Pelé do Zangado
\end{abstract}

\title{
Federica Toldo
}

Titular de um mestrado em Antropologia Cultural e Etnologia pela Universidade de Siena (Itália), desenvolveu as suas primeiras pesquisas etnográficas em Salvador, Estado da Bahia, República Federativa do Brasil. Desde 2012, no âmbito de um doutoramento em regime de co-tutela entre o Instituto de Ciências Sociais da Universidade de Lisboa (Portugal) e a Universidade de Paris Ouest, Nanterre - La Défense (França), desenvolveu trabalhos de campo em Luanda, Angola. Os seus temas de investigação estão voltados para a teoria da acção, o ritual, a relacionalidade e as modalidades não discursivas da memória. Acerca do trabalho desenvolvido no Brasil, publicou «L'intermittence du sens dans le chant de la capoeira» (in N. Bénard e C. Poulet, Chant pensé, chant vécu, temps chanté: Formes, usages et représentations des pratiques vocales. Editions Delatour France, 2016). Sobre a pesquisa desenvolvida em Luanda publicou «Memória e imaginação histórica da origem brasileira e escrava em Luanda contemporânea» (Afro-Ásia, Salvador, $n .^{\circ} 53$, 2016).

[e-mail: federica.toldo@gmail.com] 